\title{
三次元地震記象に当てはめた時変自己回帰パラメータの性状
}

\section{1: 序}

赤池の情報量基準（AIC）のもとで，地震記象に 3 次 元時変自己回帰（時変 AR）モデルを当てはめると, $A R$ パラメータ亡して, 時変化する残差共分散(イノベー ション共分散) 行列とAR 係数行列ならびに時変 AR

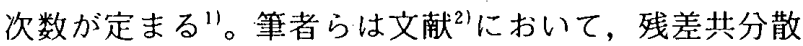
行列が震源および地震伝播経路情報を，AR 係数行列か ら定まるパルス伝達関数が地質・地形等の観測地点情報 を計量していることを見い出し，適当なパルス伝達関数 を有する系に，必要な残差共分散を有するイノベーショ ン過程を入力することで，設計用地震動を合成する手法 を提案した。本論は，この合成手法のよりどころとなっ ている残差共分散行列と震源・伝播経路との関係，なら びに文献 (2゙定義した行列ノルム伝達関数と観測地点情 報との関係について, 文献 ${ }^{2)}$ とは別の視点から詳述した ものである。本論文は，直接的には，先に提案した筆者 らの主張を補強する目的を持つものであるが，3 次元地 震記象に時変 $\mathrm{AR}$ モデルを当てはめて得られる $\mathrm{AR}$ パ ラメータが, 地震工学的に興味ある知見をもたらす証左 ともなっている。本論の前半は，イノベーション過程の 振動主軸と地震断層の走向方向との関連を調べた内容と

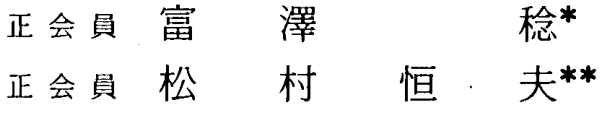

なっているが，これとは別に，地震動自体の振動主軸と 地震断層域との関係を調べた論文として久保 ${ }^{3)}$ がある。 久保は, 地震動を定常ランダム過程と確定強度関数の積 で近似できるとする立場から, Penzien と渡部の手法 ${ }^{4}$ によって上述の関係を調べた。イノベーション過程は， 線形予測問題の立場でみれば，現在までの地震動記録を もとに 1 時刻先の未来值を最良線形予测したときの予測 誤差である'が，動的システム理論からみれば，地震動 を出力とする時変線形システム注1) の力であ $る^{2)}$ 。確率過程としての地震動とイノベーション過程の このような違いが, Penzien, 渡部および久保の結果と 本論の結果との違いとなって現れていると考えれば興味 深いものがある。

以後の論述では，表一 1 に載せた 11 組の地震記象に 対して 3 次元時変 AR モデルを当てはめた結果を引用 している。表一1 の地震記象は，運輸省港湾技研資料 ${ }^{5}$ に公表されている強震計による加速度記録波形より抜す いしたものである。(S-番号が技研資料に対応) 時変 $\mathrm{AR}$ モデルの当てはめは，これらの加速度記録波形を， 文献 ${ }^{2)} て ゙$ 述べた仕様によって処理した速度波形の組に対 して行った。その際，選択された時間空長さの変化を図

表一1 時変 $\mathrm{AR}$ モデルを当てはめた地震記象

\begin{tabular}{|c|c|c|c|c|c|c|}
\hline No. & 強祳計による地震記鳋 & 震 & 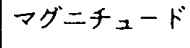 & 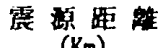 & & 発生年月日（時刻） \\
\hline 1 & $(S-234)$ & 1968 年十勝沖（本震） & 7.9 & 290 & $60 *$ & 1968年 5月16日 ( $9: 49)$ \\
\hline $1 \mathrm{~A}$ & H $(S-241)$ & 1968 年十勝沖（余震） & 7.5 & 194 & 56 & 1968年 5月16日. (19:39) \\
\hline 2 & 稆 $(S-235)$ & 1968年十勝沖 (本䬸) & 7.9 & 243 & $60 *$ & 1968年5月16日（9:49) \\
\hline 3 & $\ddot{F}(S-252)$ & 1968 年十勝沖（本彭） & 7.9 & 189 & $60 *$ & 1968年.5月16日 ( $9: 49)$ \\
\hline 4 & 古 $(S-236)$ & 1968年十勝种（本震） & 7.9 & 189 & $60 *$ & 1968年 5月16日 ( $9: 49)$ \\
\hline $4 \mathrm{~A}$ & 古 $(S-1204)$ & 1978年宮城罢神（本躼） & 7.4 & 170 & 59 & 1978年 6月12日 $(17: 14)$ \\
\hline $4 B$ & 古 $(S-11104)$ & 1978年宫城罢神（前震） & 6.7 & 107 & 58 & 1978年 2月20日 (13:37) \\
\hline 5 & 徭釜工㙏 $(\mathrm{S}-12201)$ & 1978年宫城贯种（本䗅） & 7.4 & 107 & $60 *$ & 1978年 6 月12日 $(17: 14)$ \\
\hline 6 & 小名 㑟 $(S-1191)$ & 1978年宫城罢沖（本震） & 7.4 & 178 & $60 *$ & 1978年 6月12日 $(17: 14)$ \\
\hline 7 & $g^{g}(\mathrm{~S}-2.213)$ & \begin{tabular}{|lllllll}
1 & 9 & 6 & 8 & 年 & 日 间 鹳 \\
\end{tabular} & 7.5 & 127 & 50 & 1968年 4月 1日（9:42) \\
\hline $7 \mathrm{~A}$ & 雇 $(S-544)$ & 宮聺 & 6.7 & 74 & 32 & 1970年 7月26日 ( 7:41) \\
\hline
\end{tabular}

*60 (秒) 以上のデータは、解析対象から除いた。

* 東京理科大学 教授・工博

** 東京理科大学 助手 (昭和 60 年 4 月 5 日原稿受理) 


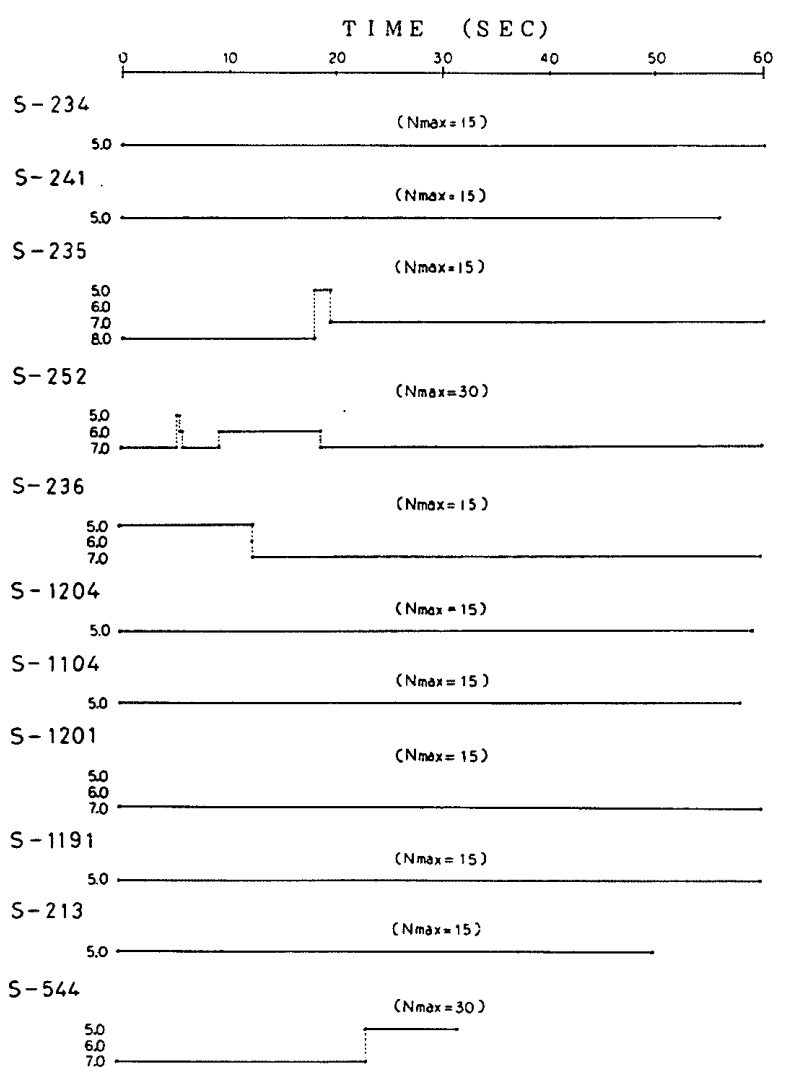

図一1 時間悹長さの変化と AR 次数検索範用 $\left(N_{\max }\right)$

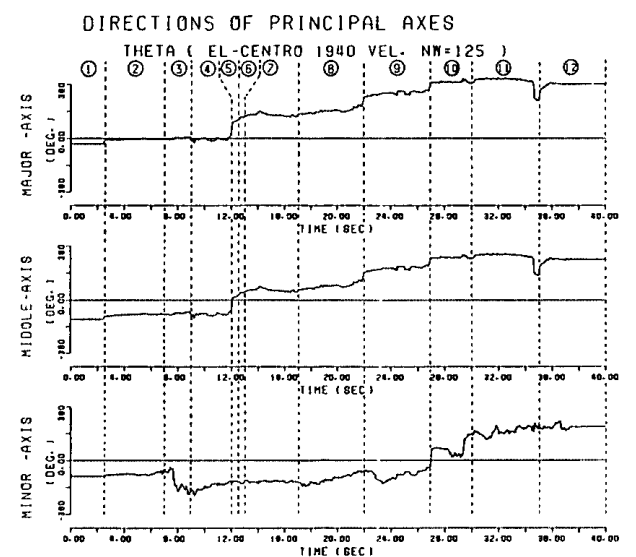

図一2 残差主分散軸の水平射影方向

TIME-VARYING OIRECTION OF MAJUR-AXIS

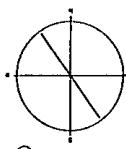

(1) 10.0.2.2..6\%

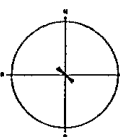

(8) 1...........1
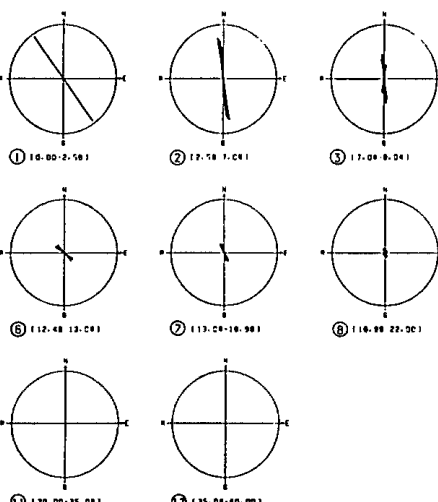

(3) 1...……1

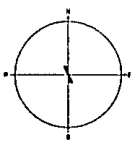

(2) 119.6.1.4\%,

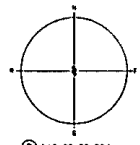

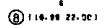

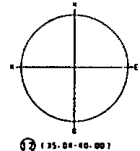

図一3 最大残差主分散値と主分散軸水平射影方向の棒グラフ表 示
-1に示す。

\section{2. 地震断畨とイノベーション過程の関係}

平均ゼロの非定常白色時系列であるイノベーション過 程を特長付ける時変残差共分散行列と震源・伝播経路亡 の間には，文献 ${ }^{21}$ におて，同一地震を異なる地点で観 測した地震記象あるいは震源距離やマグニチュードの異 なる観測記象に対する当てはめ結果から，密接な䵅りの あることが見い出されている。しかしその関係は，地震 の巨視的パラメータ等に対して間接的に証明されたもの であり, 地震発生の本体である地震断層の存在に対して 直接的に立証されたものではない。そこで本節では，時 変残差共分散行列の主分散軸（固有ベクトルの方向）, すなわち 3 次元イノベーション過程の振動主軸方向と， 地震断層の走向方向との関係について調べてみる。

図一2 は，EL-CENTRO 1940 年地震動の 3 次元速度 波形に当てはめを行って定まる時変残差共分散行列の直 交する 3 つの固有ベクトル（残差主分散軸）の方向を表 示したものである。図示の方向は，3次元の空間べクト ルである大・中・小 3 つの固有ベクトルの水平射影成分 についてのみ表示し,垂直射影成分については割愛した。 角度は, 真南を零度に採り, 真南加ら右迴りに正, 左迴 りに負と表示した。図一 3 は，最大残差主分散値の大き さと主分散軸の水平射影の方向とを 0.08 秒ごとに棒グ

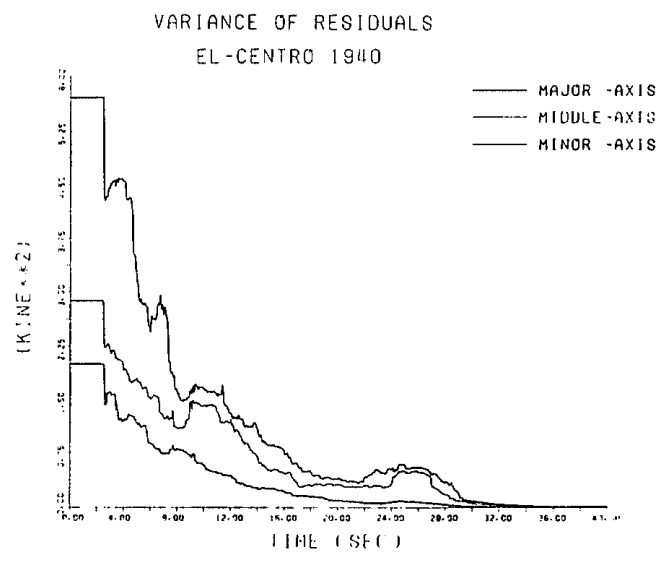

図一4 残差主分散值（EL-CENTRO 1940）

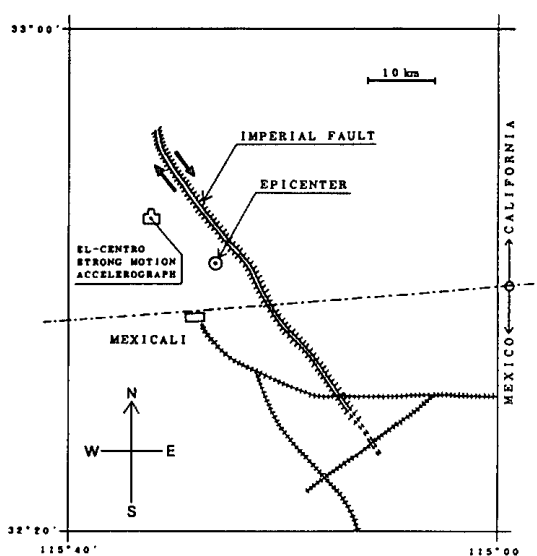

図一5 EL-CENTRO 1940 年地震動の観測所と地霞断層の位置 
ラフで表示したものである。棒グラフの長さが大きさを 示し，傾きがそのまま方向を表している。図一3中の時 間区分の識別記号(1)，(2)，…., は図一2のそれに対志 している。図一-3あるいは図一4(文献”) より，ELCENTRO 1940 年地震動のイノベーション過程は, 時 間区分(1)すなわち初期に分散值がピークとなっているこ とが分かる。

一方，図一5に示したのは，EL-CENTRO 1940 年地 震動の観测所と右ずれ地震断層であるIMPERIAL FAULT との位置を示した地図である6 。図一 3 と図一 5 を比較すると, 時間区分(1)のピーク分散值をもつイノ ベーション過程の最大振動主軸の水平射影の方向が，地 震断層の走向方向とまったく一致していることが分か る。

しかし，本例のように，観測地点と地震断層が $10 \mathrm{~km}$ 以内と接近している場合には，P 波と $\mathrm{S}$ 波がほとんど 同時に観測地点に到達するので，残差時系列がゼちらの 波のイノベーションか判らない。もし P 波より生成さ れるイノベーション過程であるなら，その最大振動主軸 の水平射影の方向は震央を指すであろうし，S 波初動以 後の波より生成されるのであれば，地震断層の走向方向

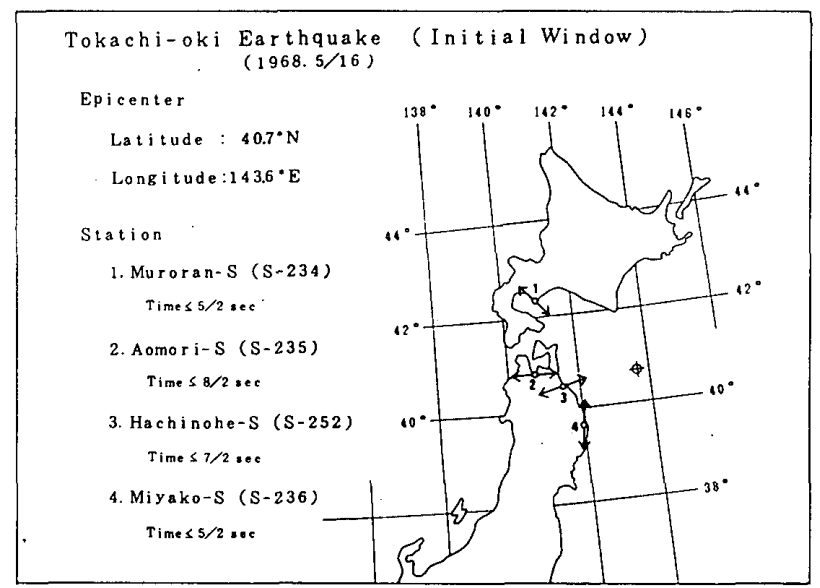

図一6 最大残差主分散軸の水平射影方向 (初動時, 十勝沖地震)

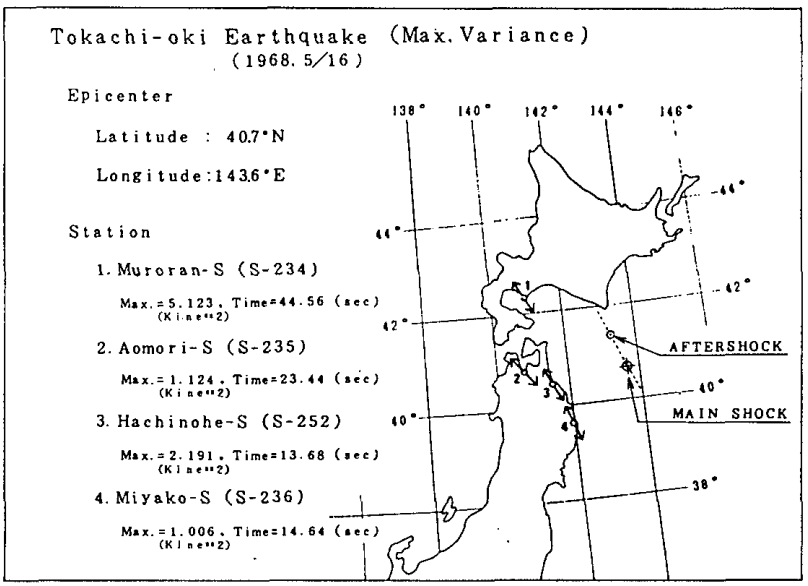

図一7 最大残差主分散軸の水平射影方向（ピーク時, 十勝沖地 霞)

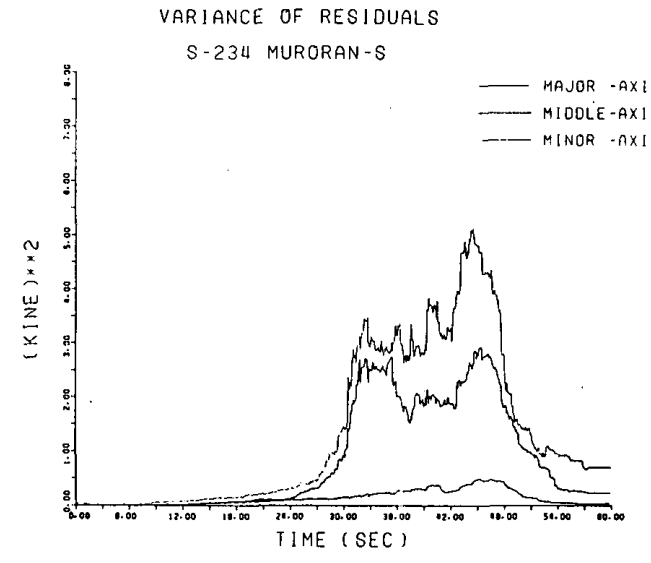

図一8 残差主分散値 (No.1, 室蘭)

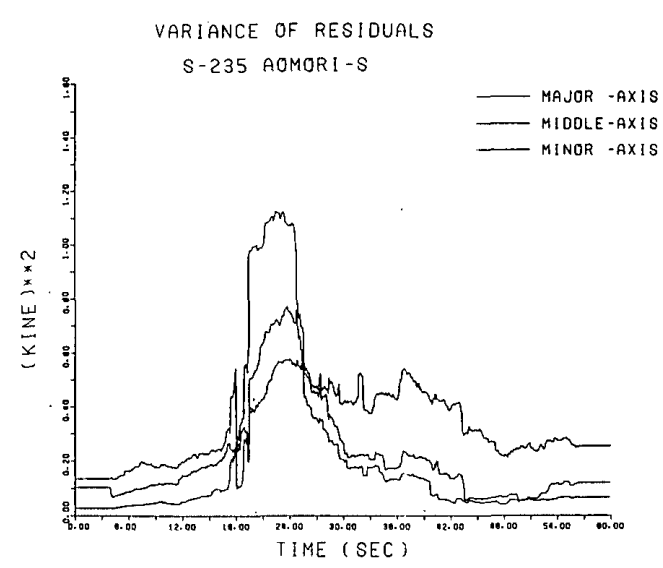

図一9 残差主分散值（No.2，青森）

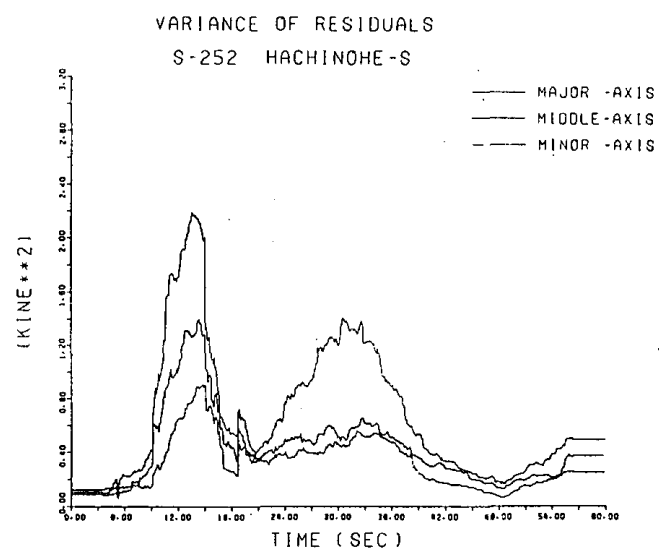

図一10 残差主分散値（No.3，八戸）

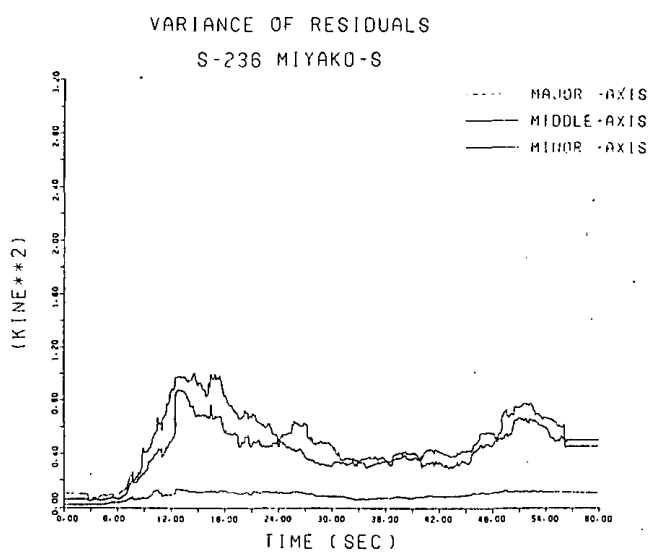

図一11 残差主分散値（No.4，宮古） 
となんらかの相関をもつであろう。この予想を以下のご とく調べてみる。

図一6 は，1968 年 5 月 16 日（9：49）に発生した十勝 沖地震 (本震) を, 室蘭, 青森, 八戸, 宮古の 4 地点で 観测した地震記象に対して時変 AR モデルの当てはめ を行い，初動部分の記録注2)に対して定まった最大残差 主分散軸の水平射影の方向を表したものである。当ては めに際して選択された始発時間空長さは, 室蘭（No.1, S-234）と宮古（No.4, S-236）については 5 秒, 青森 (No.2, S-235) は8 秒, 八戸 (No.3, S-252) につい ては 7 秒となっている。図一6に示した方向は，これら 始発時間窓内のデー夕より定まったものであり, 時間空 長さの中央点での值とみることができる゙。図一6から 判るように，最大残差主分散軸の水平射影の方向は，ほ ぼ震央を指している。4つの観測地点の震源距離が 189 $\mathrm{km}$ 以上あることと, 図一6の方向がすべて記録の初動 より 4 秒以内に定まっていることを考えると，地震学の 知見より，これらの方向が $\mathrm{P}$ 波より生成されたイノベー ション過程の振動主軸方向であることは明らかである。

図一7は,やはり同じ 4 か所の観測地点において, そ

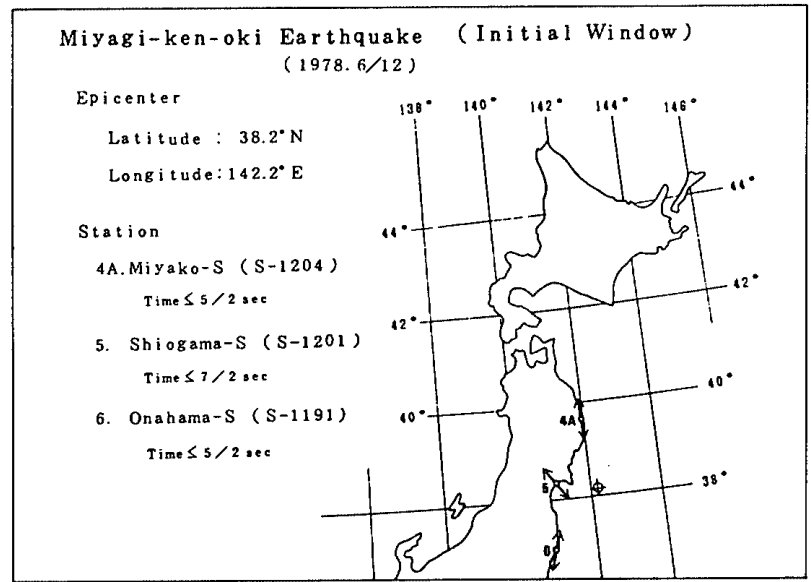

図一12 最大残差主分散軸の水平射影方向（初動時, 宮城県沖 地震)

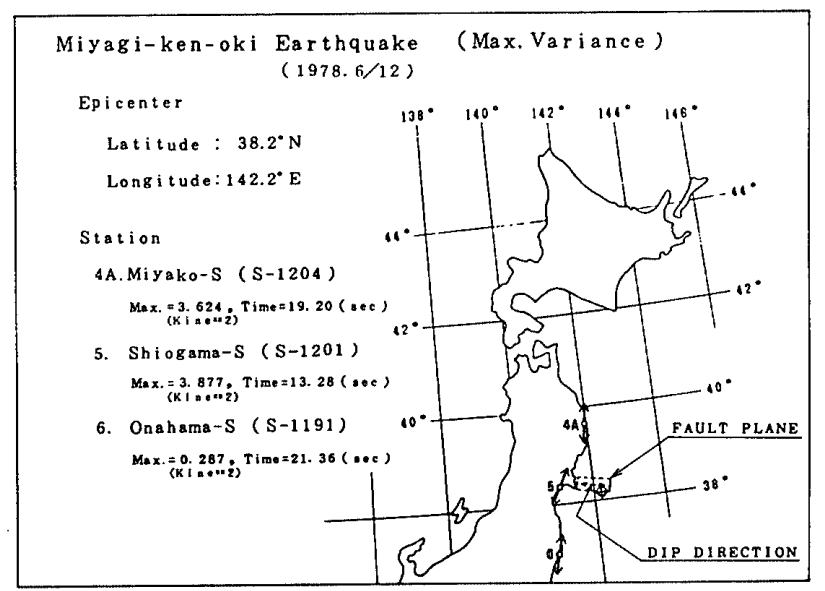

図一13 最大残差主分散軸の水平射影方向（ピーク時, 宮城県 沖地震）
れぞれの地点で最大残差主分散值がピークを示した時 の，主分散軸の水平射影の方向を示したものである。ま た図中, 申印は1968 年十勝沖地震 (本震) の震央を示し, ○印は 9 時間 50 分後に起ったマグニチュード 7.5 の余 震の震央 $\left(41.4^{\circ} \mathrm{N}, 143.3^{\circ} \mathrm{E}\right)$ を示す ${ }^{7)}$ 。本震, 余震と もに震源深さは $20 \mathrm{~km}$ である。図一7より明らかなごと く, 4 地点でのピーク時最大残差主分散軸の水平射影の 方向は, 本震の震央と余震の震央を結んだ線の方向に一 致している。この発生時間の近接した本・余震の震央を 結んだ線は, 地震断層の走向方向を代表していると考え られる ${ }^{8)}$ ので，図一7 は前述の予想を肯定しているとい
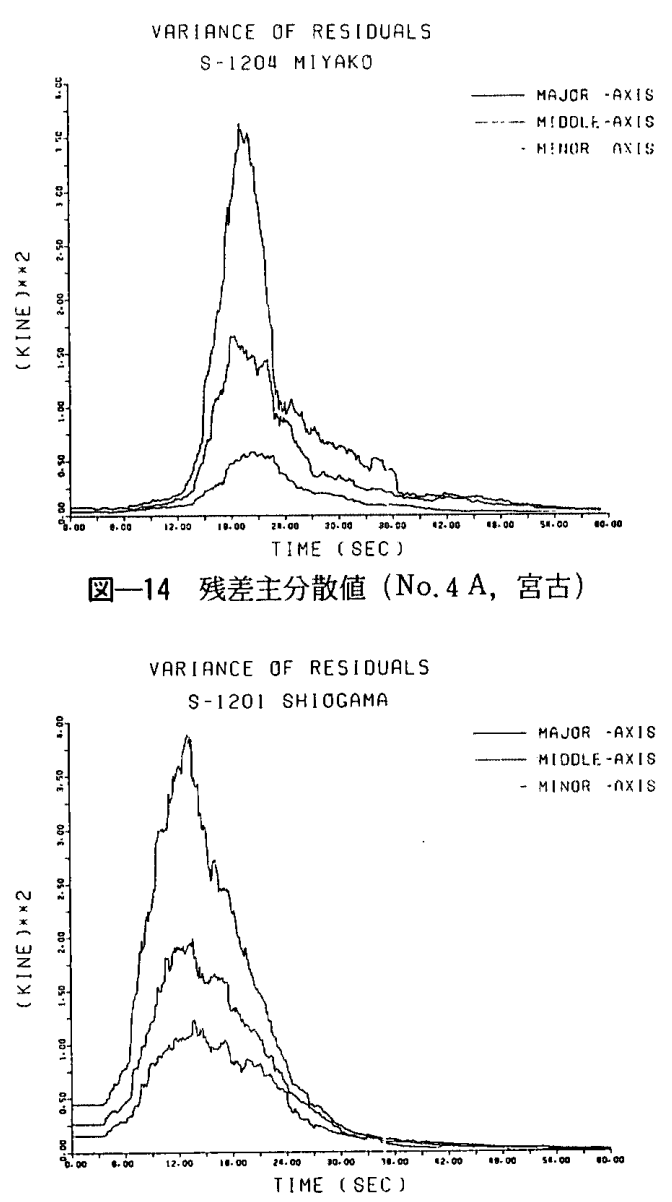

図一15 残差主分散値（No.5，塩釜工場）

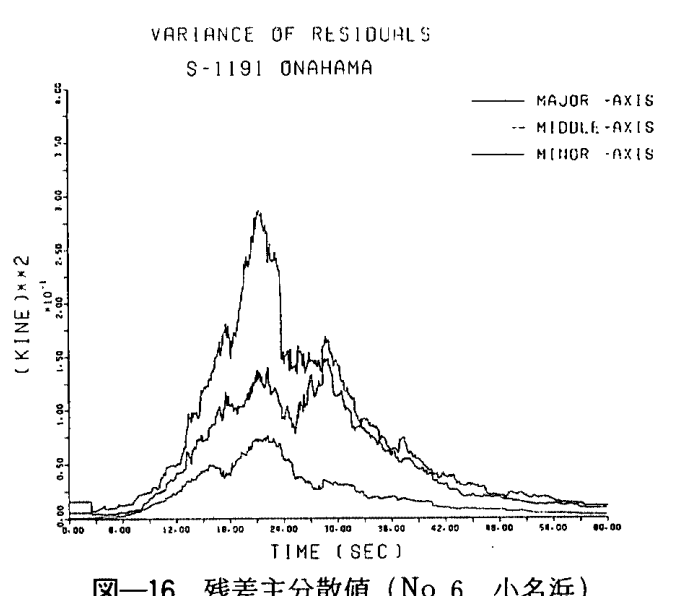

図一16 残差主分散值（No.6，小名浜） 
えよう。なお, 1968 年十勝沖地震 (本震) の室蘭, 青森, 八戸，宮古の 4 地点での 3 次元地震記象に対して定まる 時変残差主分散值のグラフを, それぞれ図一8, 図一9, 図一10および図一11 に示す。本震の震央から等距離に ある八戸と宮古の場合には，図一10 と図一11に見られ るごとく，残差主分散值はそれぞれ明瞭な 2 峰形を呈し ているが, より遠い室蘭と青森の場合はそれが崩れてい る。このことは, 地震波動の伝播経路についての未解読 情報と考えれば，大変興味深いものがある。

以上と同じ調查を, 今度は地震断層パラメータが比較 的詳しく分っている 1978 年 6 月 12 日の宮城県沖地震 (本震) について行ってみる。図一12 は, 宮古, 塩釜 工場, 小名浜の 3 地点で観測した地震記象の初動部分に 対して定まった最大残差主分散軸の水平射影の方向を表 したものである。この場合も，観測点：塩釜工場を除い て，ほぼ震央を指している。図一13は, 同じ 3 地点で 最大残差主分散值がピークを示した時の, 主分散軸の水 平射影の方向を示したものである。また図中に，瀬野そ の他 ${ }^{9}$ による断層面の長さ $(30 \mathrm{~km})$ と幅 $(80 \mathrm{~km})$ ，お よび伏角 $20^{\circ}$ で下方に傾いている断層面の傾斜方向 ( dip direction; $\mathrm{N} 280^{\circ} \mathrm{E}$ ) を示した。一見して分かるように, この例でも 3 地点でのピーク時最大残差主分散軸の水平 射影の方向は，断層面の傾斜方向に直交する方向，すな わち走向方向にほぼ一致しており，十勝沖地震の解析結 果之調和している。次いで, 1978 年 6 月 12 日宮城県沖 地震の宮古, 塩釜工場, 小名浜の 3 地点での 3 次元地震 記象に対して定まる時変残差主分散値のグラフを, それ ぞれ図一14, 図一15，および図一16に示す。これら 3 図を比較すると，まず，いずれも単峰形であることを知 る。次に, ピークの出現する時刻が, 塩釜工場 $(107 \mathrm{~km})$, 宮古 $(170 \mathrm{~km})$, 小名浜 $(178 \mathrm{~km})$ と震源距離の遠くな るに従って遅くなっていることに気付く。また逆に, 近 い程ピーク値が大きくなっていることも分かる。これら の所見より, 残差主分散値が, 地震断層の挙動ならびに 波動伝播についてなんらかの情報を担っているとみて差 支えないであろう。

\section{3. 行列ノルム伝達関数の性状}

筆者らは, 文献 ${ }^{2)}$ において, 時変 AR 係数行列 $\boldsymbol{a}(T)$ のノルムをとって定義した周波数伝達関数 ${ }^{2(3)}$.

$$
\begin{aligned}
& \bar{G}_{r}(f, T)=\left[1+\sum_{i=1}^{r}\left\|\boldsymbol{a}_{r, l}(T)\right\| \exp (-j 2 \pi f \Delta t i)\right]^{-1} \\
& \left\|\boldsymbol{a}_{r, i}(T)\right\|=\left[t_{r} \boldsymbol{a}_{r, i}^{\prime}(T) \cdot \boldsymbol{a}_{r, i}(T)\right]^{1 / 2}
\end{aligned}
$$

が, 襲来地震の規模, 方向, 距離によらず, 地震動観測 地点固有の特性を表す情報であることを主張した。その 主張の裏付けとして, 異なる震源からの大きさも違う複 数の地震動を同一地点で観測した場合に，（1）式で示 す行列ノルム伝達関数のグラフが類似のパターンとなる
ことを挙げた。しかし，「類似」の度合の認定となると， ビのような条件と尺度のもとで認定を行うのか必ずしも 明確でなかった。本節では, この点の検討を行い, 条件 と尺度を明らかにする。

ある特定の地点で観測された複数の地震動に対して定 まる行列ノルム伝達関数のグラフを相互に比較するとき に，留意しなければならない点は次の 4 点である。(1) グラフの座標軸は規格化されているか。(2) 複数の地 震記象の間に,なにか観測条件の変化はなかったか。( 3 ) 何次の AR 係数行列に対してノルムをとったか。(4) 時変 $\mathrm{AR}$ モデルの当てはめに際し, AR 次数は最高何次 まで検索したか。以下，これら 4 点について，順を追っ て論述する。

[座標軸の規格化について] 行列ノルム伝達関数が示 す增幅率は，地震記象によっては数倍以内に納まる場合 もあれば, 数十倍から数百倍に達する場合もあり一定し ない。したがって，增幅率を表す縦座標軸の最高目盛を どう採るかで，グラフの印象が異なってきて，公平な比 較が困難になる。これに対処する一案として, 本論では 以後, 零倍から十倍までは通常のユークリッド目盛, 十 倍を超える倍率に対しては対数目盛を当てることとし， これを表示規格として統一する。

[観測条件の変化について］同一観測地点で採録され た震源の異なる 2 つの地震動記録波形に,なんらかの統 計的処理を施して両者を比較しようとするとき，当然両 者の観測条件は同じでなければならない。ところが強震 計記録となると,その採録間隔は数年に及ぶ場合もあり， 2 つの地震動記録波形の間には観測条件の変化, 例えば 強震計近傍での掘削, 土地造成, 浚渫, 構造物の建設, これらに伴う地下水の変動, 等が起り得る場合もある。 しかし，このような観測条件の変化を厳密にチェックす ることは, 実際面で困難が伴う。むしろ, 観測条件の変 化を考慮外にできる位短い採録間隔の 2 つの地震動記録 波形に統計的処理を施し，その結果をこの問題に対する 標準尺度とし，それからの偏差を判断の重み付けに用い る方が実際的である。

図一17 と図一18 は, 1968 年十勝沖地震の本震 $(M=$ 7.9) と余震 $(M=7.5)$ を室蘭で観測した地震動に対し て定った行列ノルム伝達関数のグラフである。この場合, 本震と余震の時間差は 9 時間 50 分であるから, 観測条 件の変化はなかったと見てよいであろう。すなわち, 規 格化された座標上に表現された同一観測地点の行列ノル 厶伝達関数は, 観測条件が同じなら, 図一17 と図-18 に見られる程度の類似を亦す。

[ノルムをとった行列の次数について] 座標軸を規格 化し, 観測条件を吟味しても, なお行列ノルム伝達関数 同士の比較に大きな影響を及ぼす因子がある。それは, $\mathrm{AR}$ 係数行列のビの部分マトリックスに対してノルムを 


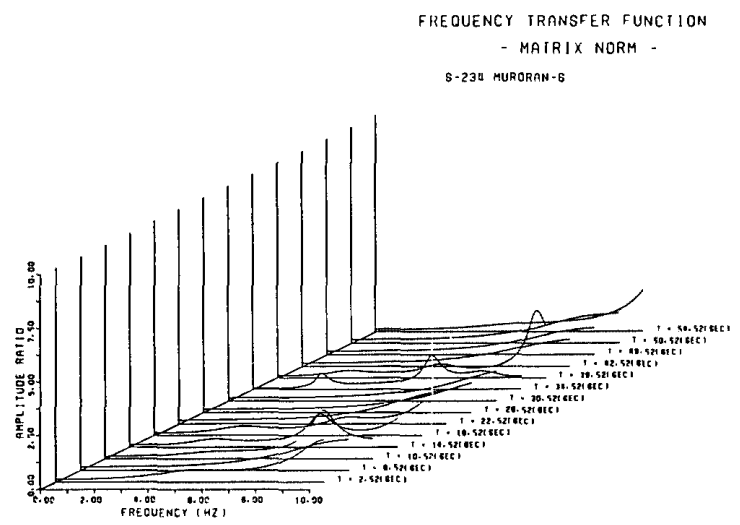

図-17 (3×3) 次行列ノルム伝達関数 (No.1, 室蘭)

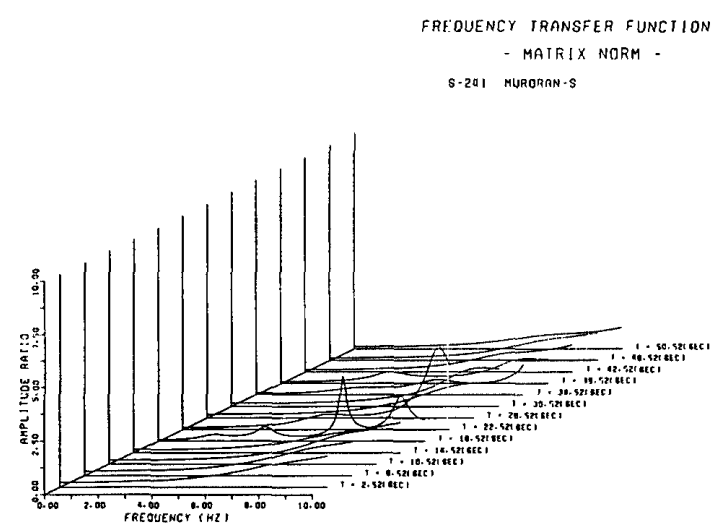

图一18 $(3 \times 3)$ 次行列ノルム伝達関数 (No.1 A, 室蘭)
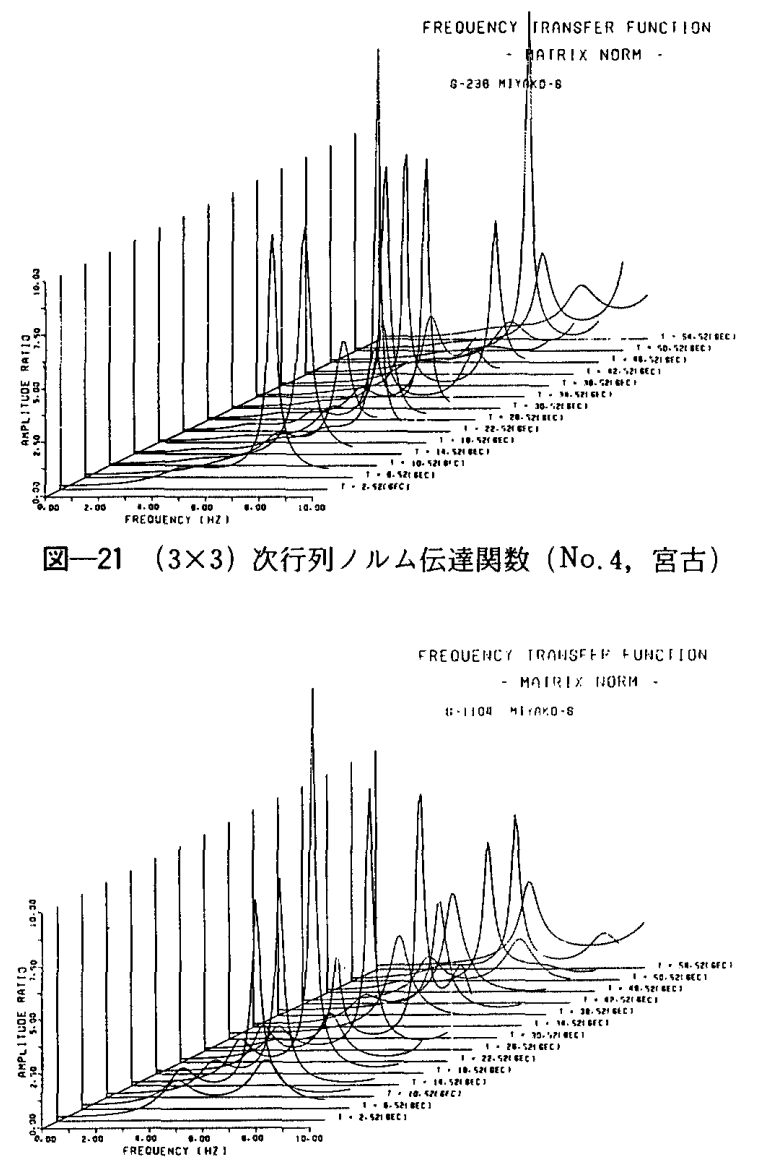

图-22 $(3 \times 3)$ 次行列ノルム伝達関数 (No.4B, 宮古)

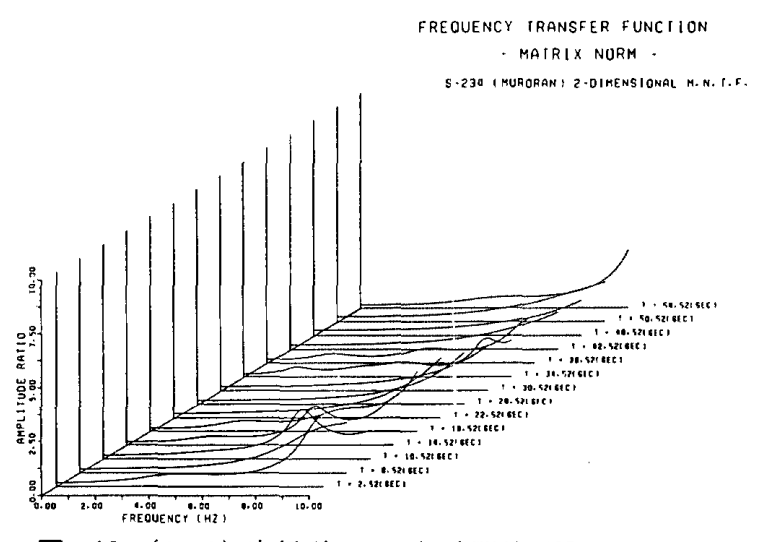

図一19 $(2 \times 2)$ 次行列ノルム伝達関数（No.1, 室蘭）
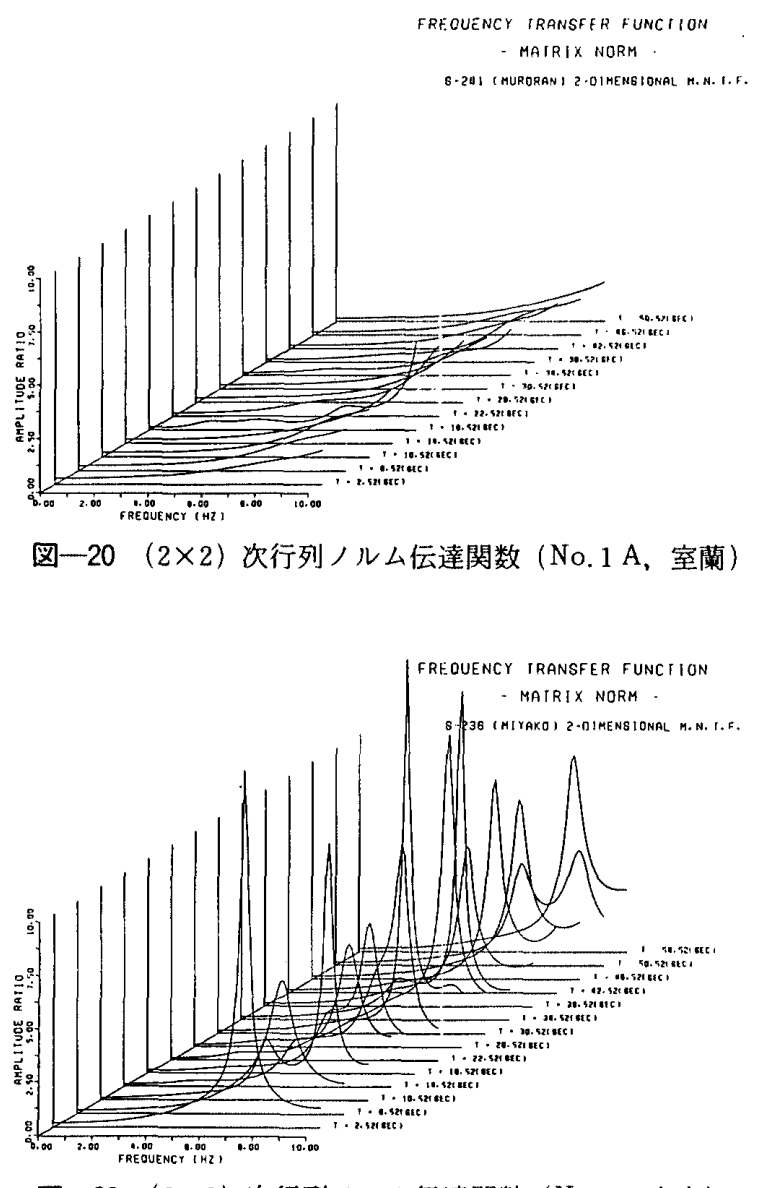

图一23（2×2）次行列ノルム伝達関数（No.4, 宮古）

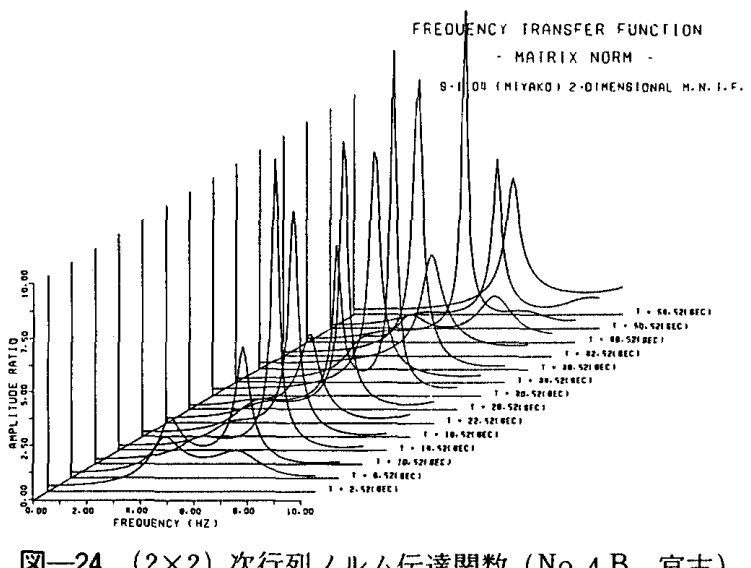

$-6-$ 
とったか，ということである。一般に，地震記象は地震 動の水平直交 2 成分と鉛直成分の計 3 成分を記録したも のである。ところが現実の地動には，これら 3 成分に加 え, 水平直交 2 軸と鉛直軸廻りの 3 つの回転成分が存在 する。すなわち，本来ならば，地震記象は 6 成分でなけ ればならない。しかし通常は 3 成分しか手に入らないと ころから，地震記象に当てはめた AR 係数行列の次数 は $3 \times 3$ ということになる。したがって，3×3のAR 係 数行列に対しノルムをとっても, 実際は $6 \times 6$ 行列之な るべき真の係数行列の部分マトリックスに対しノルムを とっているに過ぎないことになる。さらに，地震動に忠 実に追従（tracking）させるという意味からは，時変 AR モデルの当てはめに用いる地震記象の成分は多い 程, すなわち情報が多い程よいが; 観測地点の特性を代 表させるという意味からは, AR 係数行列のどの部分、 トリックスに対しノルムをとるかは別問題である。

そこで,前出の室蘭で採録された 2 組の記象について, 地質・地形等の観測地点情報を代表する成分として水平 動 2 成分を採り，それに対応した行列ノルム伝達関数を 計算したのが, 図一19 と図一20である（時変 AR モデ 儿は 3 成分に対し当てはめ)。図一 17 と図一19, 図一18 と図一20を比較して判るように, $2 \times 2$ 次行列ノルム伝 達関数は，3×3 次のそれに比べ，より簡素な表現となっ ている。以上の事情を，別の観測地点で採録された記象 について調べるため，文献”にも載せた観測地点;宮古の 2 組の記象（表一1 のNo. 4 と No. 4 B）について再計 算した結果を，図一 21 から図一 24 に示す。

この内, 図一 21 と図一 22 は文献 ${ }^{21}$ の図とまったく同 じ $3 \times 3$ 次行列ノルム伝達関数のグラフであるが, 新し く規格座標軸上の表現とした。図一 23 と図一 24 が, 宮 古で観測した 1968 年十勝沖地震（本震）と 1978 年宮城 県沖地震（前震）の記象をもとに計算した $2 \times 2$ 次行列 ノルム伝達関数である。この場合でも $2 \times 2$ 次の方が, より簡明な表現となっている。

本例のように，襲来方向もほとんど正反対に近く，規 模 $(\mathrm{M}=7.9$ と $\mathrm{M}=6.7)$ も震源距離 $(189 \mathrm{~km}$ と $107 \mathrm{~km})$
も異なる地震に対しても，観測地点が同じなら，行列ノ ルム伝達関数はこのように類似な様相を示す。

[当てはめに用いた最高 AR 次数について］赤池が 指摘しているように ${ }^{101} ， 3$ 次元 AR モデルは AR 次数が $(2 \sim 3) \sqrt{N} / 3$ を越えると, 数値計算の精度が低下する 場合がある。ただし $N$ はデー夕数。このことは，時間 㲅内の 3 次元時変 AR モデルについても成り立つ。し かし，時変 $\mathrm{AR}$ モデルの場合は，時間窓をはずれたデー 夕が総て零という訳ではないので，時間空内データ数の 2 倍程度を $\mathrm{N}$ と置けよう。したがって本研究では, 最 小時間悹長さを 5 秒，サンプリング時間々隔を 0.04 秒 として, $\sqrt{2(5 / 0.04)} \doteqdot 15$ までを最適次数の標準検索範 囲とし，時間窓長さを $5 \sim 10$ 秒と変化させてもAIC の 值が単調娍少型となる場合に，上限を 30 として範囲を 㹡げている。

さて，本論でこれまでに例示した行列ノルム伝達関数 の算定に関連して当てはめを行った地震記象 (No.1, No. 1 A, No.4, No.4B) は, いずれも 15 以内の最適

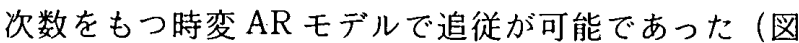
-1 参照)。しかし， $3 \times 3$ 次行列ノルム伝達関数表現亡 して文献 ${ }^{21}$ に載せた観測地点; 細島の 2 組の記象 (No. 7 と No. 7 A) となると, No. 7 が 15 以内, No.7 A が 30 以内之, No. 7 A の方に精度の低下が見られる。 この事実が，図一25 と図一 26 の比較から分かるように， たとえ規格化座標軸を採り，2×2 次の行列ノルム表現 を採ろうとも，図一 26 のグラフに細かい波が重㸚っ ている原因と思われる。すなわち，地震記象のサンプリ ング・データに対し標準検索範囲を越える最適次数で時 変 AR モデルの当てはにゔ遂行されたときには，得ら れた AR 係数行列に乱れ（誤差）が含まれていること を承知しておく必要がある。

なお，最適次数が標準検索範囲を越えないようにする には，恐らく原記象からのサンプリングをやり直す（例 えば全体的に僅かずらす等）より他に，根本的な是正手 段はないであろう。

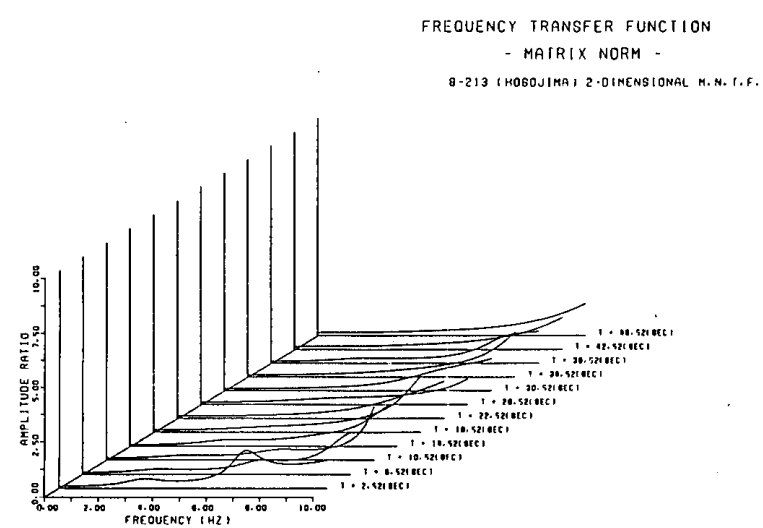

図一25（2×2）次行列ノルム伝達関数（No.7, 細島）

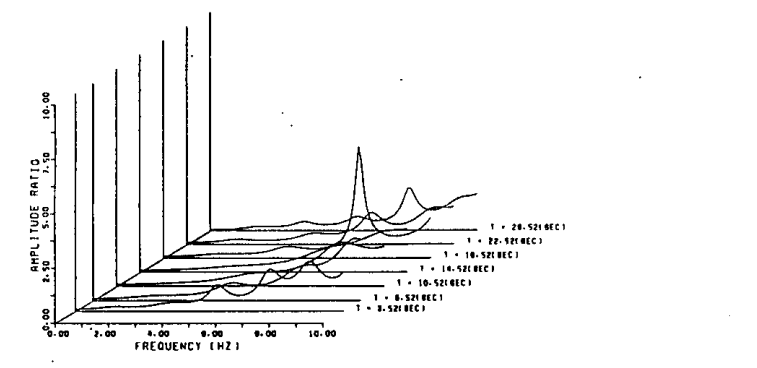

図一26 (2×2) 次行列ノルム伝達関数 $($ No. $7 \mathrm{~A}$, 紐島) 


\section{4. 結 論}

まず，第一に，これまでの解析結果より，3 次元地震 記象のサンプリング時系列に時変 AR モデルを当ては めて得られるイノベーション過程の振動主軸方向と, 震 央および地震断層の走向方向とは密接に関連しているこ とが判明した。すなわち，イノベーション過程が $\mathrm{P}$ 波 より生成されている場合には, その最大振動主軸の水平 射影の方向は震央を向き, S 波初動以後の波より生成さ れている場合には, 最大残差主分散值がピークとなる時 に地震断層の走向方向と平行するらしいことが分った。

第二に, 統一した表示規格のもとで, 時変 AR 係数 行列の水平動 2 成分に対応した部分マトリックスに関し てノルムをとった行列ノルム伝達関数の方が, AR 係数 行列そのもののノルムをとった場合よりも, 鮮明に地 質・地形等の観測地点情報を表すことが分った。

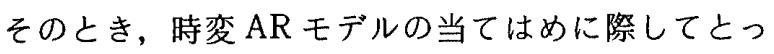
た最適 AR 次数の検索範囲に注意し，15を越えた次数 で当てはめが行われていた場合には，計算精度の低下に より行列ノルム伝達関数のグラフに乱れが生じてくるこ とをあらかじめ承知しておく必要があることを指摘した。 また，同一観測地点で採録された複数の地震記象に対し て最適 AR 次数が 15 以内で算定された行列ノルム伝達 関数でも，理由のつかない乱れが現れたときには，観測 条件の変化を疑ってみる必要があることも指摘した。し かし, 観測条件にも変化がなく, 数值計算に付随する諸 条件をすべて充足した場合でも，もともと $6 \times 6$ 次行列 となるべき AR 係数行列の部分マトリックスに対して ノルムをとって行列ノルム伝達関数を算定するのである から, 乱れがまったくないという訳にはいかない。現状 でほぼ理想に近い条件の場合を本文中に例示した。

以上要するに, 本論文は, 時変 $\mathrm{AR}$ 係数行列が観測 地点に付随する情報を担い, 時変残差共分散行列が震 源・伝播経路に関する情報を担っているという筆者らの 主張 ${ }^{2} を ，$ 新事実と改良した資料をもとにさらに補強し

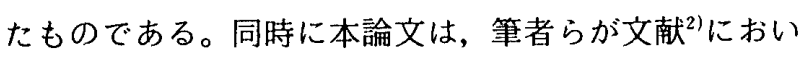
て提案した合成地震動作成手法の基礎付けともなってい る。

注

1）非均質な土質構成をもつ現実の地盤上の，しかも強震時 の地震動記録に「線形」システムを当てはめることに基 本的な疑問を抱くことは極めて当然である。この点に関 して，筆者らは次のごとき見解を採っている。いま，文 献 ${ }^{2)}$ 表記法にならい, 地震動 $\boldsymbol{Z}(t)$ が次の非線形システ 么方程式で生成されるとしよう。

$\left.\begin{array}{l}\dot{X}(t)=\boldsymbol{f}(\boldsymbol{X}(t), t)+\boldsymbol{E}(t) \boldsymbol{w}(t) \\ \boldsymbol{Z}(t)=\boldsymbol{C X}(t)+\boldsymbol{v}(t)\end{array}\right\}$

(A1) 式中の状態方程式に対応する非線形離散型状態方 程式を下記とする。

$\boldsymbol{X}(k+1)=\boldsymbol{g}(\boldsymbol{X}(k), k)+\Gamma(k+1, k) \boldsymbol{w}(k)$
関数 $\boldsymbol{g}(\boldsymbol{X}(k), k)$ を, 任意点 $\boldsymbol{X}^{*}(k)$ の迴りにテーラー展開 する。

$$
\begin{aligned}
\boldsymbol{g}(\boldsymbol{X}(k), k)= & \boldsymbol{g}\left(\boldsymbol{X}^{*}(k), k\right)+\boldsymbol{\Psi}\left(\boldsymbol{X}^{*}(k), k\right)\{\boldsymbol{X}(k) \\
& \left.-\boldsymbol{X}^{*}(k)\right\}+\cdots \cdots
\end{aligned}
$$

ただし

$$
\mathbf{\Psi}\left(\boldsymbol{X}^{*}(k), k\right)=\left[\begin{array}{ccc}
\frac{\partial g_{1}}{\partial x_{1}} & \cdots & \frac{\partial g_{1}}{\partial x_{n}} \\
\vdots & & \vdots \\
\vdots & & \vdots \\
\frac{\partial g_{n}}{\partial x_{1}} & \cdots & \frac{\partial g_{n}}{\partial x_{n}}
\end{array}\right]_{\boldsymbol{X}=\boldsymbol{X}^{*},}
$$

$\left(g_{t}\right.$ と $x_{i}$ はそれぞれベクトル $\boldsymbol{g}(\boldsymbol{X}(k), k)$ と $\boldsymbol{X}(k)$ の $i$ 番 要素)ここで高次の微分係数の項を省略して得られる状 態方程式と，観測方程式を併記すると次のシステム方程 式を得る。

$$
\begin{gathered}
\boldsymbol{X}(k+1)=\boldsymbol{\Psi}(k+1, k) \boldsymbol{X}(k)+\boldsymbol{u}(k)+\Gamma(k+1, k) \boldsymbol{w}(k) \\
\boldsymbol{Z}(k)=\boldsymbol{C} \boldsymbol{X}(k)+\boldsymbol{v}(k) \\
\ldots \ldots \ldots \ldots \ldots \ldots \ldots \ldots \ldots \ldots \ldots \ldots \ldots \ldots \ldots \ldots \ldots \ldots \ldots \ldots \\
\text { ただし } \\
\boldsymbol{\Psi}(k+1, k)=\boldsymbol{\Psi}\left(\boldsymbol{X}^{*}(k), k\right) \\
\boldsymbol{u}(k)=\boldsymbol{g}\left(\boldsymbol{X}^{*}(k), k\right)-\boldsymbol{\Psi}\left(\boldsymbol{X}^{*}(k), k\right) \boldsymbol{X}^{*}(k)
\end{gathered}
$$

この $\boldsymbol{u}(k)$ は, 線形解軌道を非線形解軌道に近すけるため の制御力とみなすことができる。すなわち，(A3）のシ ステムでは, 駆動力 $\boldsymbol{\omega}(k)$ と制御力 $\boldsymbol{u}(k)$ および観測雑音 $\boldsymbol{v}(k)$ によって地震動 $\boldsymbol{Z}(k)$ が生成されている。これとは 別に, 制御力のない次の時変線形システム

$$
\left.\begin{array}{l}
\boldsymbol{X}(k+1)=\boldsymbol{\Psi}^{\prime}(k+1, k) \boldsymbol{X}(k)+\Gamma^{\prime}(k+1, k) \boldsymbol{w}(k) \\
\boldsymbol{Z}^{\prime}(k)=\boldsymbol{C} \boldsymbol{X}(k)+\boldsymbol{v}(k)
\end{array}\right\}
$$

を考え, 極く短い時間窓内に限り $\boldsymbol{Z}^{\prime}(k)=\boldsymbol{Z}(k)$ となるよ うに $\Phi^{\prime}(k+1, k)$ と $\Gamma^{\prime}(k+1, k)$ を同定しようとするのが 本論の立場である。この作業は時々刻々, AIC 基準のも とでの最適モデルを検索する形で行われるので, 同定は 常に修正を受ける。したがって, 地震記象全体に対して は良好な追従性をもつ時変線形システムが時変 $\mathrm{AR} モ テ ゙$ ルの形で得られることになる。

2）本論で取り扱っている地震記象はすべて強震計による記 録である。強震計記録は, 周知のように, 計器が初動を 感知してから記録を開始するため, 真の初動記録は久落 している。したがって, 始発時間悹内データに当てはめ た AR モデルは，真の初動部分記象の特性を反映してい ないことに留意する必要がある。

3）行列ノルム伝達関数は, 以下のような考え方で導入され ている。地震記象 A, B があり, 同じ時間空 $[S, T]$; $S \leq k \leq T$ 内で当てはめた多次元 $\mathrm{AR}$ モデルを次の 2 式 としよう。

記象 A; $\boldsymbol{X}(k)+\sum_{i=1}^{r} \boldsymbol{a}_{i}(T) \cdot \boldsymbol{X}(k-i)=\boldsymbol{e}(k) \cdots \cdots \cdots(\mathrm{B} 1$ a $)$

記象 B; $\boldsymbol{Y}(k)+\sum_{i=1}^{s} \boldsymbol{b}_{i}(\boldsymbol{T}) \cdot \boldsymbol{Y}(k-i)=\boldsymbol{f}(k) \cdots \cdots \cdots \cdots(\mathrm{B} 1 \mathrm{~b})$

lag operator $q^{-1}$ を用いて上式を書き改めると次式とな

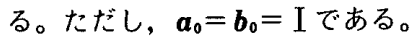

記象 A; $\left[\sum_{i=0}^{r} a_{i}(T) q^{-i}\right] X(k)=e(k)$ (B2 a )

記象 $\mathrm{B} ;\left[\sum_{i=0}^{s} \boldsymbol{b}_{i}(T) q^{-i}\right] \boldsymbol{Y}(k)=\boldsymbol{f}(k)$

この両者を, 直交変換に不変な量であるノルムで比較し ようとするのが本論の立場である。 
$\boldsymbol{e}(k)$ のルムをとると次式が書ける。

$$
\begin{aligned}
\|\boldsymbol{e}(k)\| & =\left\|\left[\sum_{i=0}^{r} \boldsymbol{a}_{i}(T) q^{-i}\right] \boldsymbol{X}(k)\right\| \\
& \leq\left\|\sum_{i=0}^{r} \boldsymbol{a}_{i}(T) q^{-i}\right\| \cdot\|\boldsymbol{X}(k)\| \\
& \leq \sum_{i=0}^{r}\left\|\boldsymbol{a}_{i}(T)\right\| q^{-i} \cdot\|\boldsymbol{X}(k)\| \cdot
\end{aligned}
$$

ここで両辺の逆数をとると，有界な形の表現として，次 式を得る。

$$
\frac{\|\boldsymbol{X}(k)\|}{\|\boldsymbol{e}(k)\|} \geq\left[\sum_{i=0}^{\dot{r}}\left\|\boldsymbol{a}_{i}(T)\right\| q^{-i}\right]^{-1}
$$

すなわち，e(k)が確率過程であるから，現実には陽な形 で比較できない入出力ベクトルのノルムの比の代りに, 上式右辺で比較しようとする訳である。奏際には，(B1) 式を $z$ 変換すれば, lag operator は $q^{-i}=z^{-i}$ 亡決まるか ら， $z^{-1}=e^{-J w \Delta t}=e^{-j 2 \pi s \Delta t}, j=\sqrt{-1}$ とおき, 次の行列， ルム伝達関数を定義して比較を行っている。

$$
\bar{G}_{\tau}(f, T)=\left[1+\sum_{i=1}^{r}\left\|\boldsymbol{a}_{i}(T)\right\| \cdot \exp (-j 2 \pi f \Delta t i)\right]^{-1}
$$

ただし，用途が比較のためだけであるから，\|I\|十1と おいている。

\section{参考文献}

1）、富澤 稔，松村恒夫：三次元地震動の時変自己回帰モデ ル, 日本建築学会論文報告集, 第 342 号, p. 1-11，1984 年 8 月。
2）富澤 稔，松村恒夫，出水俊彦：時変自己回帰モデルに よる三次元地震動の合成, 日本建築学会構造系論文報告 集, 第 349 号, pp. 10-21，1985 年 3 月。

3）久保哲夫：三次元地震動の模擬作成に関する研究（その 1 地震動の主軸), 日本建築学会論文報告集, 第 265 号, pp. $81-91,1978$ 年 3 月。

4) J. Penzien and M. Watabe: Characteristics of 3-Dimensional Earthquake Ground Motions, Earthquake Engineering and Structural Dynamics, Vol.3, p. $365-373,1975$.

5）運輸省港湾技術研究所：港湾技研資料，80 号，98号, 116 号, 250 号, 319 号, 338 号, (昭 44.6 昭 55.6)

6) M. D. Trifunac and J. N. Brune : Complexity of Energy Release during the Imperial Valley, Carifornia, Earth. quake of 1940, Bulletin of the Seismological Society of America, Vol.60, No.1, pp.137-160, Feb., 1970.

7）運輸省港沙局：1968 年十勝沖地震, 港湾被害報告, 津波 調查報告, 1968 年 12 月。

8）宮武 隆：断層の破壊過程と余震分布, 地震, II , 第 38 巻, 第 1 号, pp. 67-79, 1985 年 3 月。

9）瀬野徹三, 須藤 研, 江口孝雄：1978 年 6 月 12 日宮城 県沖地震の発生機構, 地震学会講演予稿集, No.2, p. 36, 1978。

10）赤池弘次, 中川東一郎：ダイナミックシステムの統計的 解析と制御, サイエンス社, 1972。

\title{
SYNOPSIS
}

UDC : $550.34: 512.8: 624.042 .7$

\section{PROPERTIES OF TIME-VARYING AUTOREGRESSIVE MODEL'S PARAMETERS FITTED TO THREE-DIMENSIONAL SEISMOGRAM}

\author{
by Dr. MINORU TOMIZAWA* and TSUNEO MATSUMURA** \\ Members of A.I. J.
}

To prove the relationship between seismic innovation process and attributes of the earthquake fault and to present the existence of pulse-transfer-function expressing the observation-site characteristics are aims of this paper. This paper gives the proofs that horizontal projection of major principal axis of initial motion of the innovation process, which is generated from the time-varying autoregressive model fitted to the velocity seismogram, points to the epicenter and horizontally projected direction of major principal axis of peak value of the innovation process agrees with the striking direction of the earthquake fault.

This paper also presents that the matrix-norm transfer funcion, which is defined by means of taking norm with respect to the autoregressive coefficient matrices, indicates the observation-site characteristics such as the nature of soil and geographical features, etc. This fact is independent of magnitude, hypocentral distance and hypocentral location of the earthquake event whose seismogram was used for identifying the autoregressive coefficient matrices.

* Prof., Department of Architectural Engineering, Science University of Tokyo.

** Research Assist., Department of Architectural Engineering, Science University of Tokyo. 